\title{
Collective Identity in the Andean Community: An Institutional Account*
}

\section{Identidad colectiva en la comunidad andina: una aproximación institucional}

\author{
Germán Camilo Prieto**
}

Recibido: 15/05/2015

Aprobado: 14/07/2015

Disponible en línea: 30/11/2015

\begin{abstract}
This article assesses the ways in which regional institutions, understood as norms and institutional bodies, contribute to the formation of collective identity in the Andean Community (AC). Departing from the previous existence of an Andean identity, grounded on historical and cultural issues, the paper takes three case studies to show the terms in which regional institutions contribute to the formation of three dimensions of collective identity in the AC. Namely, these are the cultural, ideological, and inter-group dimensions. The paper shows that although the ideas held about an Andean collective identity by state representatives and Andean
\end{abstract}

Resumen

Este artículo evalúa la forma en que las instituciones regionales, entendidas como las normas y los órganos institucionales, contribuyen a la formación de identidad colectiva en la Comunidad Andina (CAN). Partiendo de la existencia previa de una identidad andina, basada en elementos históricos y culturales, el artículo toma tres estudios de caso para mostrar los términos en que las instituciones regionales contribuyen a la formación de tres dimensiones de la identidad colectiva en la CAN, a saber: la dimensión cultural, la ideológica y la intergrupal. Este trabajo muestra que aunque las ideas de una identidad colectiva Andina que tienen los funcionarios

doi:10.11144/Javeriana.papo20-2.ciac

* Artículo de investigación. The present article is based on a paper presented at the XXII IPSA World Congress, Madrid 2012, at the Panel "Theorising the Role of Identity in the Unfolding of Regionalism: Comparative Perspectives". The author wishes to thank his panel colleagues, Ana Bojinovic-Fenko, Amitav Acharya, Mikhail Molchanov, Sergio Caballero, and specially Nikki Slocum-Bradley for their insightful comments. This work was part of the author's doctoral research project at the University of Manchester.

${ }^{* *}$ Profesor Asistente del Departamento de Relaciones Internacionales, Facultad de Ciencia Política y Relaciones Internacionales de la Pontificia Universidad Javeriana. Doctor en Ciencia Política de la Universidad de Manchester, Reino Unido. Correo electrónico: prieto-g@javeriana.edu.co / gcprietoc@gmail.com 
General Secretariat (AGS) bureaucrats hold are very diverse, the $\mathrm{AC}$ institutional framework provides a strong basis for the emergence of collective identity among member states. Three explanations are provided in this regard: First, the benefits obtained from Andean norms and regional institutional organisms make states identify with the regionalist project and with each other. Second, regional organisms provide spaces for state interaction where state representatives learn from each other and identify between them. Third, the AGS operates as an independent agent that exerts pressure over member states to keep the pace of regionalism. The paper argues that these explanations account for an effect of 'institutional inertia' that has helped to maintain the AC regionalist project.

\section{Keywords}

Andean community; regionalism; constructivism; identity; institutions

\section{Cómo citar este artículo:}

Prieto, G. C. (2015). Collective Identity in the Andean Community: An Institutional Account. Papel Político, 2O(2), 585-604. http:// dx.doi.org/10.11144/Javeriana.papo20-2.ciac estatales y los de la Secretaría General Andina (SGA) son muy diversas, la estructura institucional de la CAN proporciona una sólida base para el surgimiento de una identidad colectiva entre los Estados miembros. Tres explicaciones se proveen en este sentido: en primer lugar, los beneficios obtenidos de las normas andinas y de los organismos institucionales regionales hacen que los Estados se identifiquen con el proyecto regional y con los demás miembros. En segundo lugar, los organismos regionales proveen espacios para la interacción entre los Estados, donde los funcionarios estatales aprenden unos de otros y se identifican entre ellos. En tercer lugar, la SGA funciona como un agente independiente que ejerce presión sobre los Estados miembros para mantener el ritmo del regionalismo. El artículo sostiene que estas explicaciones dan cuenta de un efecto de inercia institucional' que ha ayudado a mantener el proyecto regional de la CAN.

\section{Palabras clave}

Comunidad andina; regionalismo; constructivismo; identidad; instituciones 
The Andean Community (AC) is a mainly state-led regionalist project that has been built on significant assumptions of collective identity amongst Andean countries (Colombia, Peru, Ecuador, Bolivia and, until recently, Venezuela $\left.{ }^{1}\right)$. On the one hand, there is a set of ideas of "Andinity", which refer to the common past of these countries in terms of the indigenous cultural heritage from Inca peoples inhabiting the Andes Mountains. On the other, there is a set of ideas which refers more to a common political fate of these countries, as they were liberated by Simón Bolívar, became independent as a single country (the Great Colombia), ${ }^{3}$ and during their nearly 200 years of existence as independent states have shared common features in their political regimes and economic structures - homogeneity type-identity (Wendt, 1999). This common fate consists of a mandate to work together and help each other facing political international challenges, as if Andean countries were 'brother countries' and 'sister nations'4 (Prieto, 2003, p. 277). These ideas about the common political fate of Andean countries can be encompassed under the concept of 'Andeanness', ${ }^{5}$ and altogether with the concept of Andinity provide grounds for the existence of an Andean collective identity previous to the creation of the AC in 1969.

The extent to which these ideas of Andean collective identity formed AC member states' decision to create the 'Andean Pact' ${ }^{\text {' }}$ is not discussed here. However, in a first section of the article some ideas corresponding to these concepts of Andean identity are put together with other ideas that, during research fieldwork, a number of interviewed state officials and regional bureaucrats outlined about the contents of the Andean collective identity. ${ }^{7}$ A second section addresses the three ways in which regional institutions contribute to the formation of collective identity among $\mathrm{AC}$ member states. And a third section offers an argument about the 'institutional inertia' generated by states'

\footnotetext{
${ }^{1}$ Venezuela left the AC in 2006, and only the other four countries remain members up to present. ${ }^{2}$ The term andinity was coined by John V. Murra (1975) in his studies about the pre-colonial history of the territories belonging to the Andean area.

${ }^{3}$ The Great Colombia (Gran Colombia) encompassed the territories of what would later constitute the countries of Colombia, Ecuador, and Venezuela. Yet, Bolívar wanted this country also to incorporate the territories of Peru and Bolivia.

4 This figure of 'fraternity' has been common place in the official discourse of these countries" political leaders, and almost always quoted in AC Presidential and Ministerial declarations.

${ }^{5}$ The term Andeanness is a creation of mine, to which conceptualisation has contributed the work of my colleague Jorge H. Rincón (2009) at the Centre of Studies for Integration and Democracy in South America - DEMOSUR.

${ }^{6}$ This was the name given to the regionalist project in 1969. In the 1980s the Andean Pact came to be named 'Andean Group', and since 1996 its official name was transformed into the current 'Andean Community'.

${ }^{7}$ Fieldwork was conducted between October 2010 and March 2011 in Bogotá, Quito, and Lima. A list of interviewees is provided as an annex at the end of the paper, omitting names and official designations for ethical reasons.
} 
identification with regional institutions and with each other, and also generated by the pressuring role of the AGS as an independent institutional agent.

This article engages a constructivist standpoint which assumes that the ideas that inform 'state thinking' can be assessed through observing the behaviour and language of the actors who perform state agency, among whom decision-making officials are some of the main ones (Finnemore, 1996; Wendt, 1999, 221, 281; Wight, 1999). A total of 19 state officials from Colombia, Ecuador, and Peru were interviewed about the role of collective identity and regional institutions in three case studies of the AC, namely: Peru's reluctance to adopt the Andean Free Trade Zone (FTZ) and the Common External Tariff (CET); collective AC negotiations of a Free Trade Agreement (FTA) with the European Union (EU); and the implementation of the Integrated Plan for Social Development (PIDS). ${ }^{8}$ All these interviewed state officials were decision makers or participated directly in decision-making at the three case studies/processes addressed. The same questions were posed in the interviews carried out on 13 AGS bureaucrats who also had direct responsibility over the unfolding of member states' negotiations on the three processes.

\section{The content of Andean collective identity}

Interviewees' answers about the contents of collective identity can be classified into three dimensions of Andean identity. A first dimension is the 'cultural' one, referring to those ideas that make people feel 'Andean' -they belong to the Andean region- that do not have an ideological connotation, and are not exclusively shared by national officials and regional bureaucrats. A second dimension is the 'ideological' one, and refers to the ideological consensus about the political organisation and the development models implemented in Andean countries, which used to exist until the early 200os. A third dimension is the 'inter-group' one, and consists of ideas referring to the 'group feeling' shared by national and regional officials when working and negotiating together. All ideas composing these three dimensions give birth to the 'we-feeling' that collective identity basically consists of (Wendt, 1999; Söderbaum, 2001; Smith, 1990).

Some ideas pointed out by interviewees as components of Andean identity correspond to ideas related to the concepts of Andinity and Andeanness suggested in the introduction of the paper. These ideas are part of the 'cultural dimension' of Andean identity, whose contents are shown in Table 1 :

\footnotetext{
${ }^{8}$ In Spanish, Plan Integrado de Desarrollo Social (PIDS).
} 
Table 1. The cultural dimension of Andean identity ${ }^{9}$

\begin{tabular}{|l|l|}
\hline \multirow{4}{*}{ Andinity } & Regions situated around the Andes Mountains Chain (C2, E5, A1, and A7) \\
\cline { 2 - 3 } & Cultural identity of indigenous peoples (A7 and A8) \\
\cline { 2 - 3 } & Pluri-cultural and pluri-national aspects constitutive of the Andean countries (A10) \\
\cline { 2 - 3 } & $\begin{array}{l}\text { Andean markets as the 'natural' markets of Andean countries. Trade as a source } \\
\text { of people's identification with each other (C6, P1 and A2) }\end{array}$ \\
\hline Andeanness & Andean countries as 'sons' of Libertador Simón Bolívar (C5, C6, A1, A10 and A11) \\
\hline \multirow{4}{*}{ Other ideas } & Common language (C5, A1, A7, A10 and A11) \\
\cline { 2 - 3 } & Arts and literature (C5) \\
\cline { 2 - 3 } & Biodiversity (C7 and A7) \\
\cline { 2 - 3 } & Andean citizenship (C6, C7, P2, A7 and A9) \\
\hline
\end{tabular}

Source: own work

The concepts of Andinity and Andeanness, altogether with other cultural features, such as common language and arts, are constitutive elements of the idea of 'fraternity' among Andean countries, often quoted at official discourse at the national and regional levels, ${ }^{10}$ and also pointed out by two interviewees ( $\mathrm{P}_{5}$ and $\mathrm{A} 1$ ). Biodiversity and the set of rights that the projects to constitute an Andean citizenship are trying to bring forward ${ }^{11}$ are also part of the cultural dimension of Andean identity, insofar as they were pointed out by interviewees as features that identify Andean countries' populations as a whole.

The ideological dimension of Andean identity is made of two main ideas pointed out by interviewees: first, a consensus over democracy as the political model in contrast to authoritarian rule ( $\mathrm{C} 2$ and $\mathrm{A} 11)$; and second, a consensus over free market economics, economic openness, and free trade as defining features of the development model (C2, E1, E3, P2, P4, and A11). Most interviewees claimed that these consensus were strong during the 1990 s and allowed for significant advances of regional integration and the relaunching of the Andean Pact in the form of the AC in 1996, but were broken with the arrival to power of the left-wing oriented governments of Hugo Chávez (Venezuela), Evo Morales (Bolivia), and Rafael Correa (Ecuador), which implied a breaking-off of Andean identity that persists nowadays ( $\mathrm{C}_{1}, \mathrm{C}_{2}, \mathrm{C}_{3}, \mathrm{C} 6, \mathrm{C}_{7}, \mathrm{E} 1, \mathrm{E} 2, \mathrm{E} 3, \mathrm{E} 4, \mathrm{E} 6, \mathrm{P} 4, \mathrm{~A} 5$, and A11). Finally, the inter-group dimension of Andean identity is also made of two main ideas:

${ }^{9}$ The letters and numbers in parenthesis (i.e. $C 1$ ) indicate interviewees, where $C$ is for Colombian officials, $E$ for Ecuadorian, and $P$ for Peruvian; $A$ is for AGS bureaucrats.

${ }^{10}$ See for instance García-Belaúnde (2000) and Madriz (2001). It must be clarified that neither the concept of 'andeanness' nor the one of 'andinity' appear literally quoted as such in the evidence I have compiled so far about Andean states' official discourse and official documentation of the regional institutional scheme. However, both concepts gather the ideas expressed in their definition, which have been indeed present at official discourse at both national and regional levels. ${ }^{11}$ These rights are, among others, the right to circulate within the $A C$ area without passport, the right for workers to transfer social security payments from one AC member country to another, and the right to study and work in another Andean country without the need of validating previous education degrees and diplomas. 
first, a feeling of solidarity among state representatives (E1, E3, P2, P4, A4, and A12); and second, a shared interest in strengthening states' negotiating capabilities and learning from each other (E1, E3, P2, P4, and A4).

\section{Regional institutions contributing to the formation of collective identity in the AC}

This section discusses the extent to which regional institutions, including Andean norms ${ }^{12}$, contribute to the creation and strengthening of the three dimensions of Andean identity proposed in the former section. This analysis is partly derived from interviewees' answers about the role of regional institutions, but it also draws upon some constructivist works on the relationships between identity and institutions (Acharya, 2009; Checkel, 2001; Risse, 2004; Laffan, 2004; Finnemore, 1996). Constructivists hold that institutions have socialisation and learning effects that lead to the formation of collective identity (Laffan, 2004). Checkel (2001) suggests that the reason why states comply with regional norms is because norms constitute state interests. Checkel (2001) argues that the historical and institutional context, and the experience that bureaucrats have on the issue area at play in a particular moment determine to a high extent the ways in which such bureaucrats comply with regional norms. Considering Berger and Luckmann's argument about the need of roles for creating and developing institutions, and the identification that agents generate towards the roles they assume (Berger \& Luckmann, 1968); it is possible to infer from Checkel's analysis that institutional environments make bureaucrats identify with each other and with the purpose of their jobs and carry out the tasks that institutions impose on them, including compliance with norms. In these terms, institutions create a 'bureaucratic' collective identity among state representatives.

According to Risse (2004), institutions tend to have constitutive effects on corporate actors such as national governments and interest groups, but also on individuals. Institutions affect agents' interests, preferences, and collective identities as people act in environments structured by regional institutions. As a result "We should then expect identities and institutions to coevolve [...]” (ibid.). In this same line, Acharya's work on the Association of Southeast Asian Nations (ASEAN) regionalist project claims that state interests over regional institution building led to the formation of a collective regional identity among ASEAN member states. Acharya (2009) argues that institutions and norms not only regulate state behaviour, but also redefine state interests and constitute state identities, including the development of collective identities.

\footnotetext{
${ }^{12}$ Andean norms refer mainly to 'Andean Decisions', which are the most important source of communitary law for the Andean Community. They are made by the Andean Council of Ministers, and hold a compulsory character of enforcement for member states.
} 
In the three case studies of the AC, interviewees pointed out several benefits derived from Andean norms and from the working of some AC institutional bodies that explain member states' identification with these institutions and with each other. Table 2 groups interviewees' statements on these issues:

\section{Table 2. Benefits obtained from Andean norms and regional organisms}

\begin{tabular}{|l|l|}
\hline \multicolumn{1}{|c|}{ CASE STUDY } & \multicolumn{1}{c|}{ BENEFITS } \\
\hline \multirow{4}{*}{$\begin{array}{l}\text { Peru's reluctance } \\
\text { to adopt the FTZ } \\
\text { and the CET }\end{array}$} & $\begin{array}{l}\text { The supportive role of Andean norms for Peru's trade policymaking (P1) } \\
\text { and for the making of Peru's national law (P3). }\end{array}$ \\
\cline { 2 - 3 } & $\begin{array}{l}\text { Andean norms were adapted to Peru's demands at two critical moments } \\
\text { remaining an AC member or not. These adaptations of the regional norms } \\
\text { account for an 'institutional flexibility' that might have made Peru feel } \\
\text { comfortable with remaining an AC member while not fully engaging the FTZ } \\
\text { and the CET (P2, A1 and A2).1 }\end{array}$ \\
\hline \multirow{3}{*}{$\begin{array}{l}\text { Collective FTA } \\
\text { negotiations } \\
\text { with the EU }\end{array}$} & $\begin{array}{l}\text { The supportive role of Andean norms for member states engaging } \\
\text { negotiations with third parties (C1, C4, E2, E3, A4, and A6). }\end{array}$ \\
\cline { 2 - 3 } & $\begin{array}{l}\text { Countries that had greater experience in trade negotiations offered support } \\
\text { to the countries with less experience and negotiators from these latter } \\
\text { countries learned a lot from the ones of the former ones (E1, P4 and A4).2 }\end{array}$ \\
\hline \multirow{2}{*}{$\begin{array}{l}\text { Implementation } \\
\text { of the PIDS }\end{array}$} & $\begin{array}{l}\text { The benefits obtained from concrete PIDS projects' results (E4, A7, A8, and } \\
\text { A11).3 }\end{array}$ \\
\cline { 2 - 3 } & $\begin{array}{l}\text { The supportive role of Andean norms for member states' policymaking in } \\
\text { the social area (P5 and A7). }\end{array}$ \\
\hline
\end{tabular}

Source: own work

Following the work of Bloom (1990), this paper argues that the benefits obtained from the existence of Andean norms and AC institutional bodies generate identification effects that make states identify with the AC regionalist project and with each other. According to Bloom (1990, p. 50), identification is the mechanism by which agents internalise the attitudes, modes, and behaviour of significant others, which results in agents identifying themselves as members of a group. Following Bloom (1990, p. 51), group identification is produced through the provision of material benefits or through the provision of a model that indicates the right mode of behaviour in a situation of threat. Both cases can be assessed in the list of benefits shown in Table 2.

Both when Andean norms provide support for national legislation and for AC member states negotiating with third parties, benefits and indication about the right - or at least better- way of doing things generate identification among Andean countries. Both identification processes also take place when $\mathrm{AC}$ members' national officials get together in $\mathrm{AC}$ institutional bodies or instances (like meetings, forums 
and so forth) and learn from each other and mutually support the realisation of their duties. The case of the benefits derived from the implementation of concrete PIDS projects account for the attainment of concrete material benefits. Group identification equates the emergence and reproduction of a collective identity among its members, and so it happens among AC member states thanks to the benefits obtained from the existence of Andean norms and institutions.

However, as it can be seen in Table 2, none of the statements made by interviewees allow the observation of any relationship between the benefits derived from Andean norms and institutions, and the emergence of ideas belonging to the cultural or ideological dimensions of Andean identity. Notwithstanding, it could be assumed that the cultural dimension is strengthened by the attainment of certain benefits pointed out by interviewees, like the ones of Andean citizenship, and the eventual contribution that the AC institutional framework could make for the preservation of biodiversity, and cultural values and manifestations. Yet, by looking at the inter-group dimension of Andean identity it is easier to assess the incidence of regional institutions over the cultural and ideological dimensions. The inter-group dimension was pointed out -though not referring to it as such- by those interviewees who highlighted the solidarity and group-feeling that existed among AC member states' representatives when working and negotiating together as a group. Table 3 gathers, interviewees' statements in this regard:

\section{Table 3. The inter-group dimension of Andean collective identity}

\begin{tabular}{|l|l|}
\hline Main idea & \multicolumn{1}{c|}{ Interviewees' statements } \\
\hline \multirow{5}{*}{$\begin{array}{l}\text { Solidarity } \\
\text { among state } \\
\text { representatives }\end{array}$} & $\begin{array}{l}\text { When negotiating collectively with the US there was a negotiating identity } \\
\text { among AC members' negotiators (E3). }\end{array}$ \\
\cline { 2 - 2 } & $\begin{array}{l}\text { In collective negotiations with the EU, AC members were negotiating as a } \\
\text { group, as if they were a single country (A4). }\end{array}$ \\
\cline { 2 - 2 } & $\begin{array}{l}\text { He/she had never seen any collective negotiation among Andean members } \\
\text { where they 'fought' in front of the counterpart (A4). }\end{array}$ \\
\cline { 2 - 2 } & $\begin{array}{l}\text { When one country spoke in the name of the others the [Andean] group was } \\
\text { always defended (P4). }\end{array}$ \\
\cline { 2 - 2 } & $\begin{array}{l}\text { When national officials get together in AC meetings there is a spirit of } \\
\text { confraternity and a sentiment of affinity around interests quite visible (A12). }\end{array}$ \\
\hline
\end{tabular}




\begin{tabular}{|c|c|}
\hline Main idea & Interviewees' statements \\
\hline \multirow{7}{*}{$\begin{array}{l}\text { Strengthening } \\
\text { states' } \\
\text { negotiating } \\
\text { capabilities and } \\
\text { learning from } \\
\text { each other }\end{array}$} & $\begin{array}{l}\text { There were technical capabilities of each country that, when brought } \\
\text { together, allowed to strengthen the group's negotiating capability (E3). }\end{array}$ \\
\hline & $\begin{array}{l}\text { There were countries that had greater experience in trade negotiations than } \\
\text { others, and there were also people who were more experienced in certain } \\
\text { negotiating areas, and thus they 'led' the negotiating process in those areas } \\
\text { (A4, E1, and P4). }\end{array}$ \\
\hline & Ecuadorian negotiators 'had a lot to learn' from the others (E1). \\
\hline & $\begin{array}{l}\text { In spite of the differences faced with Bolivia and Ecuador, the negotiators from } \\
\text { these two countries could strengthen their technical capabilities thanks to the } \\
\text { learning obtained from Colombian and Peruvian negotiating teams (P4). }\end{array}$ \\
\hline & $\begin{array}{l}\text { AC members learned to negotiate at the AC and learned to negotiate } \\
\text { together (A4). }\end{array}$ \\
\hline & $\begin{array}{l}\text { The AC has been a true trade negotiating school, as current member states' } \\
\text { negotiators were formed within the AC in negotiations with Mercosur, ALADI, } \\
\text { and in the FTAA (Free Trade Area of the Americas) bargaining process (E3). }\end{array}$ \\
\hline & $\begin{array}{l}\text { Collective negotiations among AC members were easier when the same } \\
\text { ideological lineaments were shared (P2). }\end{array}$ \\
\hline
\end{tabular}

Source: own work

It is clear that the emergence of the inter-group dimension of Andean collective identity is possible because of the existence of institutional bodies and instances that provide room for national officials to get together, know each other, and identify among them. Interviewees' statements about national officials' mutual support and learning from each other are also included in both Tables 2 and 3 because they account for benefits that also account for the group-feeling existing among them. Moreover, some interviewees emphasised the importance of these institutional instances for allowing state representatives to identify common problems and needs, and to agree upon common projects and policies ${ }^{13}$.

In spite of interviewees not making particular statements about ideas belonging to the cultural and the ideological dimensions of Andean identity when speaking of the role of regional institutions, their acknowledgement of the importance of institutional organisms for meeting and working together allows inferring that these institutional environments serve to reproduce some ideas composing those two dimensions. On the one hand, several Andean norms refer to these ideas in their preambles. On the other, it is easy to infer (only to infer, as no participatory observation was made in any case study) that when speaking in these institutional forums, state representatives mention some of these ideas to support their arguments.

${ }^{13}$ C6, A7, and A12. Only interviewee A7 explicitly asserted that institutional instances allowed for collective identity to emerge among $\mathrm{AC}$ member states' around common needs and policies. 
Interviewee $\mathrm{A} 7$, for instance, asserted that one effective way to make state representatives identify with each other and with the AC regionalist project was to create the institutional instances where they could meet each other and realise how much AC member countries have in common. This view is a clear example of the possibility that regional institutions create collective identity. Alternatively, interviewees $\mathrm{C}_{5}$ and $\mathrm{C} 8$ recognised that to contradict the official discourse about Andean identity (mostly referring to ideas about the cultural dimension, but also to certain extent ideas about the ideological dimension) was 'a useless act', suggesting that this discourse is so deeply embedded in the AC that even those agents that do not agree with it (like $\mathrm{C}_{5}$ and $\mathrm{C} 8$ ) reproduce it at institutional environments in the deployment of their official duties. As Finnemore points out:

[...] norms of behaviour and social institutions [...] can provide states with direction and goals for action. The values they embody and the rules and roles they define channel behaviour. Actors conform to them in part [...] because they become socialized to accept these values, rules and roles. They internalize the rules and roles as scripts to which they conform, not out of conscious choice, but because they understand these behaviours to be appropriate. (Finnemore, 1996, pp. 28-29)

In these terms, $\mathrm{AC}$ norms and institutions serve to reproduce ideas, cultural, and ideological dimensions of Andean identity.

Finally, interviewees' assessment of the role of the AGS in the three case studies show that the AGS acted as an independent agent whose supportive role was significant for the unfolding of negotiations and obtaining concrete results $\left(\mathrm{C}_{3}, \mathrm{E} 1, \mathrm{E} 4, \mathrm{P}_{5}, \mathrm{~A} 1, \mathrm{~A} 2\right.$, A4, A7 and A11). Table 4 shows interviewees' statements about the AGS supportive role in each case study:

Table 4. The AGS' supportive role

\begin{tabular}{|c|l|}
\hline Case study & \multicolumn{1}{c|}{ Interviewees' statements } \\
\hline & $\begin{array}{l}\text { The AGS was always very proactive in showing Peru why it had to resume } \\
\text { its trade obligations as soon as possible. Studies and analyses were } \\
\text { permanently made by the AGS to show Peru a clear panorama for this. }\end{array}$ \\
Peru's reluctance & $\begin{array}{l}\text { Thanks to the AGS' job there was never a total detachment so Peru never } \\
\text { to adopt the FTZ } \\
\text { treated the other AC members as third parties (A2). }\end{array}$ \\
\cline { 2 - 3 } and the CET & $\begin{array}{l}\text { Since Andean norms had a supranational character, the AGS sometimes } \\
\text { participated in negotiations as a 'sixth member state'. The AGS was } \\
\text { so strong at the beginning of the 2000s that it almost forced member } \\
\text { countries to adopt a CET (A1). }\end{array}$ \\
\hline
\end{tabular}




\begin{tabular}{|c|c|}
\hline Case study & Interviewees' statements \\
\hline \multirow{5}{*}{$\begin{array}{l}\text { Collective FTA } \\
\text { negotiations with } \\
\text { the EU }\end{array}$} & The AGS did a good job in coordinating negotiations (C3). \\
\hline & $\begin{array}{l}\text { All norms and principles that oriented collective negotiations with the EU } \\
\text { were worked out with the AGS' support (E1). }\end{array}$ \\
\hline & $\begin{array}{l}\text { It was the AGS who initiated contacts with the EU for starting negotiations } \\
\text { of an Association Agreement (E1). }\end{array}$ \\
\hline & $\begin{array}{l}\text { The AGS provided special support to Ecuador when deciding on whether } \\
\text { to continue negotiations with the EU, and the AGS also provided support } \\
\text { when Peru was negotiating its bilateral FTA with the US (A4). }\end{array}$ \\
\hline & $\begin{array}{l}\text { The support provided by the AGS to member countries during collective } \\
\text { negotiations with the EU fulfilled the expectations of Andean countries, and } \\
\text { the AGS' support has always been valued, as in FTAA negotiations and in } \\
\text { negotiations with the Mercosur (A4). }\end{array}$ \\
\hline \multirow{3}{*}{$\begin{array}{l}\text { Implementation } \\
\text { of the PIDS }\end{array}$} & $\begin{array}{l}\text { The AGS has given significant support to the Peruvian government for the } \\
\text { implementation of the PIDS (P5). }\end{array}$ \\
\hline & $\begin{array}{l}\text { The AGS tries to obtain the resources needed for developing projects and } \\
\text { member states' mandates (A7). }\end{array}$ \\
\hline & $\begin{array}{l}\text { The job of the AGS official in charge of coordinating the PIDS } \\
\text { implementation was crucial for making the PIDS survive (A11). }\end{array}$ \\
\hline
\end{tabular}

Source: own work

Regarding the negotiations of the FTZ and the CET, the AGS provided the work agendas for meetings, formulated agreement proposals, and coordinated the organisation of meetings and maintained their frequency. During collective negotiations with the EU, the AGS coordinated the logistics of negotiating rounds and provided technical support to AC member states. The same did the AGS in organising the negotiations for the PIDS' adoption and its implementation. Even though all these actions are part of the AGS' tasks assigned by AC member states, it is clear that the more or less effective way in which the AGS carries them out is up to its bureaucrats. Particularly, the AGS' proactivity in making work proposals or maintaining the frequency of meetings, and the contents it introduces to the working agendas are not implied in the tasks assigned by member states, but depend on the proactivity and work intensity of AGS bureaucrats. It is in this sense that this paper claims that the AGS acts as an 'independent agent' that reinforces member states' identification with the AC regionalist project. For the quality of support provided by the AGS and the efficiency with which it carries out its tasks (i.e. obtaining financial resources for AC projects) depend on the efficiency of the AGS bureaucrats (note for example A1's assertion that at the beginning of the 2000s the AGS behaved as a 'sixth' negotiator). Thanks to its supranational character, the AGS can act as an independent agent. To the extent that the AGS accomplishes its functions in a satisfactory manner, $\mathrm{AC}$ member states identify more with the regionalist project, inasmuch as they obtain benefits from the AGS' job. 


\section{Institutional inertia and the maintenance of the AC}

The three case studies addressed in this article also account for the AC's failure in achieving some of its main aims. Peru's reluctance to adopt the FTZ and the CET significantly hindered the achievement of an Andean common market, which was the main goal of the AC during its first 35 years of existence. Moreover, the exceptions contemplated in the Andean CET for the four AC members who adopted it (all except Peru) made it also difficult to consolidate such aim. Consolidating an Andean common market was also curtailed by the signing of bilateral FTAs by Colombia and Peru with the US in 2006, and later on with the EU in 2010, as these FTAs meant almost the complete discard of consolidating a CET in the AC. At least to certain extent, renouncing to the main historical goal of the $\mathrm{AC}$ regionalist project can be considered a failure.

Collective FTA negotiations with the EU broke in 2008 due the impossibility of agreeing common positions between Colombia and Peru on one side, and Bolivia and Ecuador on the other. Beyond the EU's condition of bloc-to-bloc negotiations, AC member states aimed at collective trade negotiations with third parties, as the negotiations with the Mercosur, the FTAA bargaining process and with the US ${ }^{14}$ had shown. At least, official AC declarations and D-667 -namely the AC Decision that oriented FTA negotiations with the EU- advocated for collectively negotiating among $\mathrm{AC}$ member states as a bloc. In these terms, the incapability of negotiating a trade agreement as a bloc can be also considered a failure, as it was also an AC aim. Finally, the social area was supposed to be the new propelling issue area of Andean integration in the mid-20oo's, facing failure in the trade area, but the PIDS made little advances and the evaluation made by interviewees of the PIDS' implementation was rather unsatisfactory.

The previous points provide room for enquiring about the sensibleness of maintaining a regionalist project that has not yielded significant results according to the main goals that it has traced. Although in recent years AC member states' Presidents spoke of renewing the regionalist project (Lima Declaration, 2011; Bogotá Declaration, 2011), there is a generalised impression that the AC has entered a period of serious decline. Moreover, Venezuela abandoned the regionalist project in 2006 arguing the lack of consistence with the purpose of deepening trade integration that implied the signing of FTAs with the US by Colombia and Peru. The 2008-2010 diplomatic crisis between Colombia and Ecuador due to the Colombian Army's bombing of a FARC guerrilla

\footnotetext{
${ }^{14}$ Colombia, Ecuador and Peru began FTA negotiations with the US under the AC regional scheme. Due to the lack of interest of Bolivia and Venezuela, these negotiations were not conceived as bloc negotiations, but the three Andean countries that undertook them started negotiating as a group in those areas where agreement existed. In 2006, the US suspended FTA negotiations with Ecuador due to legal disputes between the Ecuadorian government and some US oil companies (information provided by interviewee E3).
} 
camp located in Ecuadorian territory close to the border zone with Colombia confirmed that the AC completely lacked the cohesion and cooperation mechanisms to deal with security and political issues. Trade in the Andean region continues to be important for AC member states, but an FTZ does not need an integration process to work out ${ }^{15}$. Yet, the AGS and member countries keep on working on trade issues, the Andean Social Agenda and the Andean Environmental Agenda continue to be developed, and though the Andean Presidential Council has not met again since November 2011, up to date the Andean Council of Ministers continues to meet.

The argument is not that the AC does not provide any benefits at all. There are benefits derived from intra-regional trade, the AC institutional framework provided the conditions to negotiate an FTA with the EU that Colombia and Peru finally achieved, and the PIDS' implementation yielded some results, like the Harmonised System of Social Statistics (SISCAN) and the benefits derived from the execution of certain projects. The point is that these benefits do not seem significant enough to explain the maintenance of the $\mathrm{AC}$ regionalist project, at least not from a merely rationalist-materialist analysis based on benefit maximisation.

The constructivist standpoint engaged in the present paper allows understanding the ways in which regional institutions, considered as ideational structures, enable the emergence and reproduction of collective identity. This article has analysed the ways in which Andean norms and AC institutional organisms contribute to the formation of the cultural, ideological, and inter-group dimensions of Andean collective identity. Based on this assessment, it is possible to argue that regional institutions, to the extent that they contribute to the construction of collective identity, generate an 'institutional inertia' that contributes to explaining why the $\mathrm{AC}$ regionalist project is maintained despite of its few achievements and weakened political relationships among its member states ${ }^{16}$.

The concept of 'institutional inertia' is built upon the work of Berger and Luckmann, and to a certain extent, also upon the ones of John Searle and Alexander Wendt. According to Berger and Luckmann (1968), institutions tend to legitimise themselves. These authors speak of a "strengthening of the traditionalism in institutionalised actions", or a "strengthening of the inherent tendency of institutionalisation to inertia". On his part, Searle (1995, p. 47), considers that institutions can exist even if agents are not conscious of institutions' existence, and can also be unconsciously created and reproduced, and argues that institutions are reproduced through practice (Searle, 1995). Following Wendt,

\footnotetext{
${ }^{15}$ Today the AC is the third or fourth trade partner of each of its member states, though in no case accounts for more than a fifth of their exports.

${ }^{16}$ Clarity must be made that the fact that the $\mathrm{AC}$ has been maintained is to be understood as the $\mathrm{AC}$ not having been ended, and by no means that the $\mathrm{AC}$ will be maintained indefintely for the reasons here suggested.
} 
the fact that what we have to 'go on' in our past experience helps creating 'institutional inertia' (Wendt, 2001, p. 218).

The idea of an institutional inertia as a factor explaining the AC's maintenance derives from two core issues addressed in the three case studies considered in this article. First, institutional inertia derives from the identification effects triggered by the benefits provided by Andean norms and institutions. Second, it derives from the inter-group dimension of Andean identity. Benefits derived from Andean norms and institutions were pointed out in a previous section in relation to the supportive role of Andean norms for AC member states' policymaking; the provision and development of national legislation in those areas where member countries did not have national laws; and the opportunity to identify common needs, problems, and policies that made AC members identify with each other and with the Andean regionalist project. The benefits derived from the supportive role of the AGS are also included here. These benefits are directly related to the inter-group dimension of Andean identity, as it is national officials' interaction within AC institutional environments which allows the generation of identification effects that further derive in the emergence of the 'group-feeling' pointed out by several interviewees.

Some interviewees' assertions allow thinking of the idea of an institutional inertia in the AC. Interviewee $\mathrm{C}_{5}$ asserted that if the AC ceased to exist, there are many Andean norms in areas such as sanitary and customs issues that would need to be introduced into member states' national legislations, and 'this is no easy task' $\left(\mathrm{C}_{5}\right)$. Interviewee $\mathrm{C}_{7}$ asserted that if the AC disappeared, this would imply 'a loss' for member countries because "the AC has offered support for national processes" (C7). Interviewee A1o held that the AC is still important because there is a 'historical heritage' overall in the juridical and trade orders, as well as in 'negotiating practices', and all this has 'a meaning' for member states. In this same line, interviewee A8 held that there is 'a heritage' produced by the AC: "There is a FTZ that works and there is an institutional framework. SOCICAN (SOCICAN is the EU programme for funding social projects in the AC) provides a rotating fund to finance social projects" (A8). Interviewee A7 asserted that the Andean integration process was 'a whole', a set of actions and commitments, an institutional framework that was working for improving the life conditions of everyone in the Andean sub-region. Other assertions are related to the constraining effects of regional institutions. Interviewee A12 held that Foreign Affairs Ministries' bureaucrats keep holding AC meetings partly because there is 'a lot of pressure' to continue working with the AC. On his/her part, interviewee A11 asserted that despite that the AC was always seen by Peru as an obstacle for its international negotiations, the fact that the AGS is located in Lima makes Peru to appease its will of abandoning the AC.

Moreover, institutional inertia in the AC consists of national officials and regional bureaucrats getting used to doing things 'as they have always been done'. For instance, 
interviewee A13 explicitly asserted that "there is an identity around the AC as long as people work with the AC institutions". According to A13, working within AC institutions makes national officials and regional bureaucrats to identify with the AC. A13 asserted that when people come to work with AC institutions, be them AGS bureaucrats or national officials, people come 'as Andeans'. This interviewee added that it is procured that when new people arrive they understand that 'the regional' is different from 'the national'. In A13's view, an AC achievement has been that collective identity is incorporated in bureaucrats and national officials' consciousness.

The argument of an institutional inertia reads as follows: the benefits derived from Andean norms and institutions, plus national officials and AGS bureaucrats' interaction within AC institutional environments, generate an institutional inertia consisting of these agents assuming the practices of Andean regionalism as a habit. In other words, member states get used to working with the AC regionalist project, and AGS and other AC institutions' bureaucrats get used to the existence of the Andean integration process, to the point that never mind its advances or results, the maintenance of the $\mathrm{AC}$ is not questioned. An extreme example of the idea of institutional inertia is interviewee A11's assertion that "today the Andean Social Agenda is a pretext with which the AC bureaucrats ensure their permanence". Although this is a rather harsh statement, it gives a sense of the point to which AGS bureaucrats can stick to their job as they get used to it. The same can occur to those national officials who deal with AC issues.

Interviewee A8 asserted that regional institutions matter 'precisely' because, in spite of adverse political situations, these institutions survive. Besides accounting for the strength of AC institutions, A8's view invites wondering why, in spite of the few advances of Andean regional integration and the political differences among $\mathrm{AC}$ member states, the AC institutional framework is maintained, and sometimes even broadened, and the institutional pace of the $\mathrm{AC}$ in terms of meetings and working activities continues. The idea of an institutional inertia contributes to explain this.

\section{Conclusion}

This article has shown that, according to the views of the interviewed national officials and AGS bureaucrats, there is a strong relationship between Andean norms and institutions, and the existence of the three proposed dimensions of Andean collective identity, particularly of the inter-group dimension. This finding coincides with the reviewed constructivist literature, which holds that regional institutions enable the emergence and foster the reproduction of collective identity. Yet, what is of special interest in the AC is that the active role of regional institutions in contributing to the emergence and reproduction of an Andean collective identity can help explaining the maintenance of the regionalist project. In this regard, the argument of 'institutional inertia' has been 
developed in order to show that both national officials and AGS bureaucrats might feel identified with AC norms and institutions and with each other, thanks to the benefits derived from regional institutions. It has been argued that the AGS independent supportive role contributes to this identification process. Thanks to these benefits, and considering some constructivist tenets about the agents' tendency to reproduce -even unconsciously- institutional settings, the article has argued that the maintenance of the AC can be explained partly because of an institutional inertia consisting of national officials and regional bureaucrats getting used to acting within AC institutional environments and sticking to their jobs.

The institutional reading of collective identity in the AC offered in the present article has shown that regional institutions can play a significant role in enabling the construction of collective identity. Focusing on interviewees' views about the role of regional institutions in the unfolding of three case studies of the AC and on their considerations about the contents of Andean collective identity has been the basis to carry out the analysis. Yet, agents' motivations to build up regional institutions is a question that has remained unaddressed, and focusing on agents' views entails the problem of 'double hermeneutics' -the researcher's interpretation of agents' interpretation- pointed out by several scholars dealing with interpretivist issues (Hollis \& Smith, 1990; Wendt, 1998; Brglez, 2001). 'Bracketing' exercises, understood as analysing univocal relationships between variables that are known to be mutually influenced (Finnemore, 1996, pp. 2425; Checkel, 2001) in order to explain the effects of one over the other, lead, as Zehfuss (2002) has pointed out, to take certain issues of reality as given and thus to have a limited approach to reality as a social construction (Zehfuss, 2002; 2006).

Bracketing issues and relying on agents' views are some of the stumbling blocks that constructivism has to face in order to offer explanations on the basis of ideas. In the present article, these two problematic issues warn epistemological challenges to the way constructivism theorises about the explanatory capability of ideas. Yet, at least it is hoped that the article has shown that addressing the relationship between institutions and identity -even though just in terms in which regional institutions contribute to the construction of collective identity in the $\mathrm{AC}$ - contributes to have a better understanding of the unfolding and maintenance of regionalism.

\section{References}

Acharya, A. (2009). Constructing a Security Community in South East Asia. ASEAN and the problem of Regional Order ( $2^{\text {nd }}$ Edition). Abingdon, Oxon: Routledge.

Berger, P., \& Luckmann, T. (2003/1968). La construcción social de la realidad. Buenos Aires: Amorrortu Editores. 
Bogota Declaration. (2011, November 08)' Extraordinary Meeting of the Andean Presidential Council. Available at: http://www.cancilleria.gov.co/sites/default/files/ news/field_attached_news/Declaraci\%C3\%B3n\%2ode\%2oBogot\%C3\%A1\%20 adoptada\%20por\%20el\%20Consejo\%20Presidencial\%20Andino\%20- \%20 Bogot\%C3\%A1,\%2onoviembre\%208\%20de\%202011.pdf

Brglez, M. (2001). Reconsidering Wend's Meta-theory: Blending Scientific Realism with Social Constructivism. Journal of International Relations and Development, 4(4), 339-362.

Bloom, W. (1990). Personal Identity, National Identity and International Relations. Cambridge: Cambridge University Press.

Checkel, J. (2001). Why Comply? Social Learning and European Identity Change. International Organization, 55(3), 553-588.

Finnemore, M. (1996). National Interests in International Society. Ithaca, London: Cornell University Press.

García-Belaunde, J. A. (2000). El sueño de Bolívar: de la Federación de los Andes a la Comunidad Andina. Lecture. September 27-28. Biarritz: Comunidad Andina. Retrieved from: http://www.comunidadandina.org/documentos/docIA/IA27-9-0o.htm

Guzzini, S., \& Leander, A. (Eds.) (2006). Constructivism and International Relations: Alexander Wendt and his critics. London: Routledge.

Herrmann, R., Risse, M., \& Brewer (Eds.) (2004) Transnational Identities. Becoming European in the EU. Lanham: Rowman and Littlefield Publishers.

Hollis, M., \& Smith, S. (1990). Explaining and Understanding International Relations. Oxford: Clarendon Press.

Jones, R. (Ed.) (2001). Critical Theory and World Politics. Boulder: Lynne Rienner Publishers.

Laffan, B. (2004). The European Union and Its Institutions as "Identity Builders". In Herrmann, R. Risse, M., \& Brewer (Eds.). Transnational Identities. Becoming European in the EU (pp. 75-96). Lanham: Rowman and Littlefield Publishers.

Lima Declaration. (2011, June 28), XVIII Andean Presidential Council. Retrieved from: http://www.cancilleria.gov.co/sites/default/files/Decimo\%20Octava\%20Reunion\%2odel\%20Consejo\%2oPresidencial\%20Andino.Declaracion\%2ode\%20 Lima.28.7.2011.pdf

Madriz, J. (2001).¿Cómo transformar la dimensión cultural en motor de la integración?. Parlamento Andino. Retrieved from: http://sela.org/attach/258/EDOCS/ 
SRed/2006/03/To23600000653-o-Cómo_transformar_la_dimensi\%C3\%B3n_ cultural.pdf

Murra, J. (1975). Formaciones económicas y políticas del mundo andino. Perú: Instituto de Estudios Peruanos.

Prieto, G. (2003). Constructing regionalism in South America: the role of ideas in the Andean Community and Mercosur projects. Colombian Economic Journal, 1(1), 268-303. Retrieved from: http://www.fce.unal.edu.co/cej/number1/10-Prieto.pdf

Rincón, J. (2009). Análisis de la identidad cultural andina en el contexto de la Comunidad Andina. Graduate thesis presented to opt to the MA in Latin American Studies, Faculty of Political Science and International Relations, Pontificia Universidad Javeriana, Bogotá.

Risse, T. (2004). European Institutions an Identity Change: What Have We Learned?. In Herrmann, Richard K., Risse, M., \& Brewer (Eds.). Transnational Identities. Becoming European in the EU(pp. 247-271). Lanham: Rowman and Littlefield Publishers.

Searle, J. (1995). The Construction of Social Reality. London: Penguin Books.

Smith, A. (1990). Towards a Global Culture? Theory Culture \& Society, 7, 171- 191.

Söderbaum, F. (2001). Towards a New Regionalism Theory. The Social Construction of the International Political Economy of Regionalisation. Licentiate Thesis at the Department of Peace and Development Research at Göteborg University, Padrigu, Sweden.

Wendt, A. (1998). On constitution and causation in International Relations. Review of International Studies, 24(5), 101-118.

Wendt, A. (1999). Social Theory of International Politics. Cambridge: Cambridge University Press.

Wendt, A. (2001). What is International Relations For? Notes Toward a Postcritical View. In Jones, R. (Ed.). Critical Theory and World Politics (pp. 295-224). Boulder: Lynne Rienner Publishers.

Wight, C. (1999). They Shoot Dead Horses Don't They?: Locating Agency in the Agent-Structure Problematique. European Journal of International Relations, 5(1), 109-142.

Zehfuss, M. (2002). Constructivism in International Relations. The Politics of reality. Cambridge: Cambridge University Press.

Zehfuss, M. (2006). Constructivism and identity: a dangerous liaison. In Guzzini, S., \& Leander, A. (Eds.). Constructivism and International Relations: Alexander Wendt and his critics (pp. 93-117). London: Routledge. 


\section{Annex: List of interviewees}

Note: Because of the confidentiality form that interviewees signed at the beginning of the interviews, and given the 'uniqueness' of the responsibilities described in each case, it is not possible to reveal in this list whether interviewees occupied the described positions in the past or if they do in the present.

\section{National officials}

\section{Colombia}

C1 - One of the negotiating chiefs of the Ministry of Foreign Trade, Industry and Tourism. This person was in charge of leading FTA negotiations with the EU.

C2 - One of the Vice-ministers of the Ministry of Foreign Affairs. This person was one of the decision-makers participating in the FTA negotiating process with EU.

$\mathrm{C}_{3}$ - One of the negotiating chiefs of the Ministry of Foreign Trade, Industry and Tourism. This person was also in charge of leading FTA negotiations with the EU.

C4 - A high-level official in the Ministry of Foreign Affairs in charge of dealing with AC issues, including the FTA negotiations with the EU.

$\mathrm{C}_{5}$ - One of Colombia's Foreign Trade Ministers.

C6 - An official of the Ministry for Social Protection in charge of dealing with AC issues.

$\mathrm{C}_{7}$ - An official of the Ministry of Environment in charge of dealing with AC issues.

C8 - One of Colombia's Foreign Affairs Ministers.

\section{Ecuador}

E1 - One of the negotiating chiefs of the Ministry of Foreign Trade. This person was in charge of leading FTA negotiations with the EU.

E2 - A high-level official in the Ministry of Foreign Trade in charge of one of the negotiating tables at FTA negotiations with the EU.

E3 - One of the negotiating chiefs of the Ministry of Foreign Trade. This person was in charge of leading FTA negotiations with the US.

E4 - A Vice-Minister in the Ministry of Coordination for Social Development in charge of dealing with $\mathrm{AC}$ issues.

E5 - A high-level official in the Ministry of Coordination for Social Development in charge of dealing with $\mathrm{AC}$ issues.

E6 - An international bureaucrat who has intervened in defining Ecuador's participation in the PIDS' implementation.

\section{Peru}

P1 - One of the negotiating chiefs of the Ministry of Foreign Trade. This person was in charge of leading the negotiations of the FTZ and the CET and also the FTA negotiations with the EU. 
P2 - A high-level official in the Ministry of Foreign Trade in charge of conducting negotiations for the FTZ and the CET, and also FTA negotiations with the EU.

P3 - A high-level official in the Ministry of Foreign Affairs in charge of dealing with $\mathrm{AC}$ issues.

P4 - A high-level official in the Ministry of Foreign Trade in charge of conducting FTA negotiations with the EU.

$\mathrm{P}_{5}$ - A high-level official in the Ministry of Women and Social Development in charge of dealing with $\mathrm{AC}$ issues.

\section{AGS bureaucrats}

A1 - A high-level bureaucrat in charge of supporting negotiations for the FTZ and the CET. A2 - A high-level bureaucrat in charge of supporting negotiations for the FTZ and the CET and also FTA negotiations with the EU.

A3 - A high-level bureaucrat in charge of supporting negotiations for the FTZ and the CET.

A4 - One of the AC directors in charge of supporting negotiations for the FTZ and the CET and also FTA negotiations with the EU.

A5 - One of the AC directors in charge of supporting negotiations for the FTZ and the CET and also FTA negotiations with the EU.

A6 - A high-level bureaucrat in charge of supporting FTA negotiations with the EU.

A7 - A high-level bureaucrat in charge of developing the Andean Social Agenda and the PIDS.

A8 - A high-level bureaucrat in charge of implementing the PIDS.

A9 - A high-level bureaucrat in charge of managing EU's cooperation to the Andean Social Agenda.

A10 - One of the AC directors in charge of dealing with social issues.

A11 - A high-level bureaucrat in charge of implementing the AC's New Strategic Design in the 2000s, including the development of the PIDS.

A12 - One of the AC directors in charge of dealing with social issues.

A13 - A high-level bureaucrat in charge of implementing the Andean Environmental Agenda. 